\title{
Prevalence of Gender Based Violence Amongst Pregnant Women Accessing Ante-Natal Care in Chukwuemeka Odumegwu Ojukwu University Teaching Hospital, Amaku, Awka
}

\author{
Dr. Ifeanyi Eyisi \\ Department of Community Medicine, College of Medicine \\ Chukwuemeka Odimegwu Ojukwu University, Anambra, Nigeria
}

\begin{abstract}
Background: Gender-based violence (GBV) involves men and women, whereby the female is the victim in most cases; it arises as a result of unequal power relationships between men and women. Violence is suffered by a woman because she is a woman, and violence extremely affects women [1].Methods: This research exercise was conducted in Chukwuemeka Odumegwu Ojukwu University Teaching Hospital (COOUTH) Awka. Questionnaires were checked for errors and omissions at the end of each day. Quantitative data were entered into the computer and analyzed using SPSS version 20. Data analysis included descriptive statistics and appropriate test for associations. Cross - tabulations were done and chi - square test was used to test for associations between variables at $5 \%$ level of significance. Data errors were checked for and corrected.Results: $12.3 \%$ of the respondents have experienced some form of gender-based violence while pregnant; The most common type of violence seen amongst the pregnant women was physical abuse which grossed $65.2 \%$; The most common cause of violence amongst the study population is misunderstanding on diverse issues arising in the family; the study identified the commonest perpetrators of GBV against women to be their Husbands as it grossed 73.4\%.Conclusion: Gender based violence remains a major health concern in the society, more so in pregnant women. In the study above, $12.3 \%$ were victims of violence and this is a mirror to show how much more is seen in both pregnant and non-pregnant women.
\end{abstract}

Keywords: Gender Based Violence; Pregnant Women; Ante-Natal Care

DOI: $10.7176 / \mathrm{JMPB} / 54-03$

Publication date: April $30^{\text {th }} 2019$

\section{Introduction}

Gender-based violence (GBV) involves men and women, whereby the female is the victim in most cases; it arises as a result of unequal power relationships between men and women. Violence is suffered by a woman because she is a woman, and violence extremely affects women [1]. Being female is the key risk factor for gender-based violence. Gender Based Violence cuts across the boundaries of ethnicity, age, orientation, religion, disability, sexual \& belief and socio economic differences. It is also important to recognize that men too can experience abuse whilst women may be perpetrators, and that abuse within same sex relationships has a similar prevalence to heterosexual relationships [2].

Gender-based violence comprises of domestic abuse such as rape and sexual assault, stalking and harassment, harmful traditional practices such as female genital mutilation, childhood sexual abuse, commercial sexual exploitation, 'honour' crimes and forced marriage. It primarily affects women, even though men too can be victims of abuse [3]. Domestic abuse is a pattern of assaultive and coercive behaviours which could be physical, sexual, financial, emotional or psychological abuse, or could be a combination of any of the above factors. GBV remains one of the most severe challenges to women's well-being, as well as one of the crucial issues of equity and social justice. Indisputably, violence against women is a heinous crime by all standards, and it leaves a negative impact on women for several years while may continue with it throughout a lifetime [1].

Violence against women perpetuated by intimate partners worldwide is a major public health concern as well as human rights subject. More than 1.3 million people worldwide die each year as a result of violence in all its forms, accounting for $2.5 \%$ of global mortality. Global estimates of intimate partner violence perpetuated by men against women indicate that $30 \%$ of ever partnered women worldwide have experienced physical and/or sexual violence by an intimate partner at some point in their lives [4].

\section{Gender Based Violence and the Pregnancy}

As we know, women are susceptible to violence throughout their lifespan, but this is most common in their fertile years. Violence during pregnancy heightens during a woman's gestation with grave consequences both the woman and the fetus. Both mother and fetus suffer adverse effects, e.g., fetal death, low birth weight, preterm delivery, small size for gestational age in fetus, maternal mortality, mental health problems, kidney infections, reduced weight gain during pregnancy, and increased likelihood of undergoing operative delivery in pregnant women [1]. 
Any woman can experience abuse. Nevertheless, factors like poverty, financial dependence, disability and homelessness can increase women's vulnerability to abuse and affect their ability to avoid or escape victimization [3].

Indicators of gender-based violence in pregnancy include:

History of recurrent miscarriages, abortions, still births or pre-term labour.

Non-attendance at antenatal appointments.

Attendance with a dominant or aggressive partner who refuses to leave the room.

Numerous injuries at different stages of healing [3].

\section{Statement of Problem}

The prevalence of gender based violence amongst pregnant women accessing antenatal care is predominantly high due to age, ethnicity, disability, sexual orientation, religion \& belief and socio economic inequality. In a study carried out in selected hospitals in Abuja, Nigeria, of the 300 respondents interviewed, $129(43.0 \%)$ had ever experienced violence. The types of violence ever experienced included psychological/emotional 49(38.0\%), physical 47(36.4\%), sexual 17(13.2\%) and financial 16(12.4\%) violence. Of those who reported physical violence, $18(38.3 \%)$ were kicked in pregnancy. Of these episodes $7(38.9 \%)$ was directed at the stomachs, $6(33.3 \%)$ was directed at respondents' legs, 4(22.2\%) was directed at other parts of the body and $1(5.6 \%)$ reported that kick was directed at her head. Physical abuse was reported to be a frequent occurrence by $44.7 \%$ of respondents. Perpetrators of various violence experienced were partners/husbands (70.2\%) and partners'/husbands' relations (29.8\%) [5].

There is no data on the prevalence of gender based violence among pregnant women accessing antenatal care within the study area. This study aims at assessing the preponderance, prevalence, risk factors of GBV among pregnant women accessing antenatal care within our study area. This study will also be used to know the specific types of abuse or violence and from which relation exactly, husband or mother-in-law and also and in the study area and reasons.

\section{Objective of Study}

The primary objective of the study is to access the prevalence of gender based violence amongst pregnant women accessing ante-natal care in Chukwuemeka Odumegwu University Teaching Hospital, Amaku Awka. While the specific objectives of the study are;

1. To access the frequency of gender based violence amongst pregnant women accessing ante-natal care in COOUTH, Amaku, Awka

2. To assess the type of violence perpetrated to pregnant women accessing antenatal care in COOUTH, Amaku, Awka

3. To access the cause of gender based violence amongst pregnant women accessing ante-natal care in COOUTH, Amaku, Awka.

4. To assess the relationship of the perpetrator to the women accessing antenatal care in COOUTH, Amaku, Awka.

5. To access the response and reactions of the violated women accessing antenatal care in COOUTH, Amaku Awka.

\section{Research Questions}

How knowledgeable on GBV are pregnant women accessing antenatal care in Chukwuemeka Odumegwu Ojukwu University Teaching Hospital?

What is the frequency of gender based violence amongst pregnant women accessing ante-natal care?

What are the type of violence perpetrated to pregnant women accessing antenatal care?

What are the relationships of the perpetrators to the women accessing antenatal care in?

What are the responses and reactions of the violated women accessing antenatal care?

\section{LITERATURE REVIEW}

Violence among women is the most pervasive yet least recognized human rights violation in the world. It also is a profound health problem sapping women's energy, compromising their physical health and eroding their selfesteem.

In addition to causing injury, violence increases women's long-term risk of a number of other health problems including chronic pain, physical disability, drug and alcohol abuse and depression. Women with a history of physical or sexual abuse are also at increased risk of unintended pregnancy, sexually transmitted infections(STIs) and adverse pregnancy outcomes. For over two decades, women's advocacy groups around the world have been working to draw more attention to the physical, psychological and sexual abuse of women and to stress the need for action. They have provided abused women with shelter, lobbied for legal reforms and 
challenged the widespread attitudes and beliefs that support violent behavior against women. Increasing these efforts are having results [6].

\section{Prevalence of Gender Based Violence Amongst Pregnant Women}

In a study done in USA, it concluded that a woman's risk of physical and sexual violence during pregnancy is under-reported and underestimated [7]. Each year, over 324,000 pregnant women are victims of violence in the United States [8]. A number of countries have sought to statistically estimate the number of adult women who have experienced violence during pregnancy:

United Kingdom prevalence: $3.4 \%[7]$

United states prevalence:3.4\%-33.7\% [9] [10]

Ireland prevalence: $12.5 \%$ [11]

Population studies from Canada, Chile, Egypt and Nicaragua:6-15\% [12]

Incidence rate is higher for teenagers [13]

The incidence rate for low-income, teen mothers is as high as $38 \%$ [12]

This study showed that certain women are more likely to be abused during pregnancy than others. Women who have been abused before getting pregnant are at higher risk of violence during pregnancy [2]. In general, the rate of physical violence during pregnancy decreases as household income increases (i.e. Women with lesser income were at more risk of physical or sexual violence during pregnancy than those with higher income) [14]. A study in India was carried out in all the six geo-political zones in India i.e. Northern, Southern, Eastern, Western, Central and Northeast zones and result showed that gender based violence occurs during pregnancy across the six zones. The situations become worse for women if her husband or family perceived the pregnancy to be a female child and there is a demand for a male child [15].

\section{Types of Violence Against Pregnant Women}

In a study done in China, nature of violence during pregnancy was mainly psychological in the form of threats of abuse without any physical injury [16]. A study conducted among 950 urban pregnant women at urban hospital in Kathmandu revealed that 33\% had suffered different types of abuse of whom $47 \%$ reported psychological, $23 \%$ physical and $13 \%$ sexual abuse [17]. In a study done in Nepal, emotional abuse was the most common form of violence experienced by pregnant women (26.8\%) [17]. In Northwest Ethiopia, the nature of violence was mainly psychological (24.9\%), sexual (14.8\%), physical (11.3\%) [18].

A study done in a rural community Northwest Nigeria showed that amongst 314 respondents, 108 (34.3\%) had experienced at least one form of domestic violence and the types observed are: Verbal violence 79(68.5\%), Psychological violence 72(66.7\%) and Physical violence 55(50.9\%) [19]. While in university of Jos Nigeria, most frequent form of violence was forceful sexual intercourse $(60.9 \%)$ followed by threat $(20.3 \%)$ and slapping $(18.7 \%)[20]$.

\section{Causes of Gender Based Violence Amongst Pregnant Women}

In a study done in India, it showed that GBV became worse if the husband or family perceived the pregnancy to be a female child and there is a demand for a male child [15]. Similar study done in China pointed out unplanned pregnancy as a cause [16] and in another done in Ethiopia, the causes included inter-parental exposure of perpetrators to domestic violence during childhood [18], having frequently drinker partner and undesired pregnancy by partner. A study done in a rural community Northwest Nigeria suggested the cause of violence to be domestic issues in $63.9 \%$ of cases, financial issues in $13.9 \%$ and attending ante-natal care in $10.2 \%$. Others include having female children alone in $6.5 \%$, unplanned pregnancy in $4.6 \%$ while request to do Retro viral screening and unemployment were also identified as trigger factors in $2.7 \%$ cases each [19]. Also, a study was done in Nigeria at University of Jos and alcohol consumption by husbands, having multiple sexual partners and woman being HIV positive were the main causes of Gender based violence [20].

\section{Relationship of The Perpetrators to the Women}

A study on Gender based violence done in China revealed husbands as the perpetrators in the majority of cases. Other perpetrators included the Mother in-laws, co-wives and step-sons [16]. Another study carried out by Nepal pointed the perpetrator to be the husband (23.6\%) [17] whilst in a similar study done in a rural community Northwest Nigeria, the perpetrators were the current husband in $37.0 \%$, co-wives in $30.6 \%$ and in-laws in $23.1 \%$ [19]. In a study done in Jos Nigeria, husbands were found to be the perpetrators in $52.3 \%$ of cases [20]. Also, similar studies done in Zaria and Kano noted spouses to be the commonest perpetrators in $34 \%$ and $58.6 \%$ of cases respectively [19].

In a study done in Zaria,35.9\% of the women involved keep it a secret, $27.5 \%$ would report to their family. $15.7 \%$ would report to the doctor while others would report to the in-law, police, clergy or tell a close friend [21]. In a similar study done in Delta, some of the women felt violence in pregnancy was always (12\%) or under 
certain conditions (25\%) excusable and 77\% of them keep it secret [22].

\section{Methodology}

\section{Study Area}

Chukwuemeka Odumegwu Ojukwu University Teaching Hospital (COOUTH) Awka, a government owned tertiary institution located in the south-eastern part of Nigeria, West Africa. Awka is the third largest city in Anambra State. Awka lies between latitude $6^{0}, 12^{\prime} 25^{\prime \prime}$ North and longitude $7^{0}, 6^{\prime}$ East ${ }^{[23]}$. The temperature in Awka is generally between $23-27^{\circ} \mathrm{C}$.According to 2006 Nigerian census, Awka had an estimated population of $301,657^{[24]}$.

Chukwuemeka Odumegwu Ojukwu University Teaching Hospital (COOUTH) is in the heart of Awka and it is a State Government health facility under the State Ministry of Health (SMOH) in the south east geopolitical zone of Nigeria. The institution which was formerly a Secondary Health Center as General Hospital, Amaku Awka, was upgraded to a tertiary institution as the Teaching Hospital belonging to the state university, Chukwuemeka Odumegwu Ojukwu University, Anambra State. The hospital and its annexes since inception have provided specialized and comprehensive medical care to the immediate community and beyond. It is also responsible for undergraduate training as well as research. COOUTH provides ante-natal care to about 200 pregnant women monthly and it is the only tertiary health institution offering such care in Awka and its environment. It is open for antenatal care visits twice every week.

\section{Study population}

Pregnant women of all ages undergoing antenatal care in Chukwuemeka Odumegwu Ojukwu University Teaching Hospital, Amaku - Awka, Anambra State.

\section{Inclusion Criteria}

(a) Persons must be pregnant and undergoing antenatal care in Chukwuemeka Odumegwu Ojukwu University Teaching Hospital Amaku Awka.

(b) Clients who gave consent

\section{Exclusion Criteria}

(a) Clients who did not give consent

\section{Study Design}

The study was a descriptive, cross-sectional survey conducted using a structured questionnaire.

\section{Sample Size Determination}

The formula used is for a population $>1000$ but $<10,000$ and the total population is unknown as shown below; [25]

$$
\mathrm{N}_{\mathrm{o}}=\frac{Z^{2} p(1-p)}{\mathrm{e}^{2}}
$$

Where $\mathrm{N}_{\mathrm{o}}=$ Sample size

$\mathrm{Z}=$ standard normal deviate $=1.96$ at $95 \%$ confidence level

$\mathrm{p}=$ Prevalence $=$ proportion of pregnant women exposed to gender based violence in Nigeria according to a Nigerian study was $13 \%$, hence $p=0.13$. ${ }^{[26]}$

$\mathrm{e}=$ level of precision (degree of accuracy required) $=5 \%=0.05$

Therefore, Sample size was:

$$
\begin{array}{ll}
\mathrm{N}_{\mathrm{o}}=\frac{1.96^{2} \times 0.13(1-0.13)}{0.05^{2}} & \\
\mathrm{~N}_{\mathrm{o}}=\frac{0.43448496}{0.0025} & \mathrm{~N}_{\mathrm{o}}=173.794
\end{array}
$$

$\mathrm{N}_{\mathrm{o}} \approx 174$

Using a non-respondence rate of $10 \%=17.4 \approx 17$;

The total sample size $=174+17=\mathbf{1 9 1}$

\section{Sampling Procedure}

Systematic sampling was done on the nature of the study population, using a simple random sampling to select 
the respondents. About fifty women attend the antenatal clinic on each day (Monday and Friday). Hence questionnaires were distributed to the respondents by simple random sampling by choosing their folders at random.

\section{Research Instruments}

The study consisted quantitative and qualitative component: structured, interviewer-administered questionnaire, consisting of two sections, viz;

(a) Section A: Socio - demographic characteristics, which focused on age, sex, educational level, marital status and religion.

(b) Section B: Knowledge of gender based violence, which consisted close - ended questions that focused on the respondent's exposure and response to gender based violence

\section{Ethical Consideration}

The approval was gotten from the COOUTH Ethical Committee and a verbal consent obtained from research respondents before administration of the questionnaires. The respondents were informed about the research and its objectives and participation was made voluntary. They were assured that confidentiality will be maintained during and after the study and information given will be used only for research purposes.

\section{Data Management and Analysis}

Questionnaires were checked for errors and omissions at the end of each day. Quantitative data were entered into the computer and analyzed using SPSS version 20. Data analysis included descriptive statistics and appropriate test for associations. Cross - tabulations were done and chi - square test was used to test for associations between variables at 5\% level of significance. Data errors were checked for and corrected.

\section{Data Collection}

The structured questionnaire was distributed to the patients within a period of six weeks on the antenatal clinic days including Monday and Friday and this was strictly after seeking for the individual's consent. 
Data Results

Socio-Demographic Characteristics

Table 1: Socio-demographic characteristics of respondents

\begin{tabular}{|c|c|c|}
\hline \multirow{2}{*}{$\begin{array}{l}\text { Variables } \\
A G E\end{array}$} & Frequency $(n=187)$ & Percent (\%) \\
\hline & \multicolumn{2}{|c|}{$A G E$} \\
\hline $15-19$ & 7 & 3.7 \\
\hline $20-24$ & 32 & 17.1 \\
\hline $25-29$ & 79 & 42.2 \\
\hline $30-34$ & 53 & 28.3 \\
\hline $35-39$ & 15 & 8.6 \\
\hline others & 1 & 0.5 \\
\hline \multicolumn{3}{|l|}{ MARITAL STATUS } \\
\hline Single & 9 & 4.8 \\
\hline Married & 177 & 94.7 \\
\hline divorced & 1 & 0.5 \\
\hline \multicolumn{3}{|l|}{ ETHNICITY } \\
\hline Igbo & 169 & 90.4 \\
\hline Hausa & 8 & 4.3 \\
\hline Yoruba & 7 & 3.7 \\
\hline Others & 3 & 1.6 \\
\hline \multicolumn{3}{|l|}{ RELIGION } \\
\hline Christian & 181 & 96.8 \\
\hline Islam & 5 & 2.7 \\
\hline Traditional & 1 & 0.5 \\
\hline \multicolumn{3}{|l|}{ EDUCATION } \\
\hline Primary & 1 & 0.5 \\
\hline Secondary & 37 & 19.8 \\
\hline Tertiary & 146 & 78.1 \\
\hline None & 3 & 1.6 \\
\hline \multicolumn{3}{|l|}{ OCCUPATION } \\
\hline Unemployed & 23 & 12.3 \\
\hline Trader & 20 & 10.7 \\
\hline Civil servant & 66 & 35.3 \\
\hline Entrepreneur & 24 & 12.8 \\
\hline Student & 46 & 24.6 \\
\hline Others & 8 & 4.3 \\
\hline \multicolumn{3}{|l|}{ MARRIAGE DURATION } \\
\hline $0-2$ & 113 & 60.4 \\
\hline $3-5$ & 49 & 26.2 \\
\hline $6-8$ & 9 & 4.8 \\
\hline $9-11$ & 6 & 3.2 \\
\hline Others & 10 & 5.3 \\
\hline
\end{tabular}

\section{MARRIAGE TYPE}

\begin{tabular}{l|ll}
\hline Monogamous & 168 & 90.8 \\
Polygamous & 8 & 4.3 \\
Others & 11 & 5.9
\end{tabular}

Out of a total of 191 respondents who were approached for the study, 187 women responded to the questionnaire, giving a response rate of $97.9 \%$. From the table above, it could be deduced that seventy-nine $(42.2 \%)$ were aged $25-29$, fifty-three $(28.3 \%)$ were aged $30-34$ meanwhile 0ne $(0.5 \%)$ was older than 39 years. Almost all respondents were married (94.7\%) and nine (4.8\%) were single. One hundred and sixty-nine (90.4\%) were from the Igbo tribe while $4.3 \%$ and $3.7 \%$ were Hausa and Yoruba respectively. 96.8\% of respondents were Christians. Meanwhile, one hundred and forty-six respondents $(78.1 \%)$ had tertiary education and thirty-seven $(19.8 \%)$ had secondary education. Sixty-six respondents $(35.3 \%)$ are civil servants, forty-six $(24.6 \%)$ are students, twenty-four (12.8\%) are entrepreneur and twenty-three $(12.3 \%)$ are unemployed.

One hundred and thirteen $(60.4 \%)$ have been married for $0-2$ years while forty-nine $(26.2 \%)$ have been married for 3-5 years. One hundred and sixty-eight $(90.8 \%)$ respondents are married in a monogamous family setting while eight $(4.3 \%)$ are in polygamous family setting. 


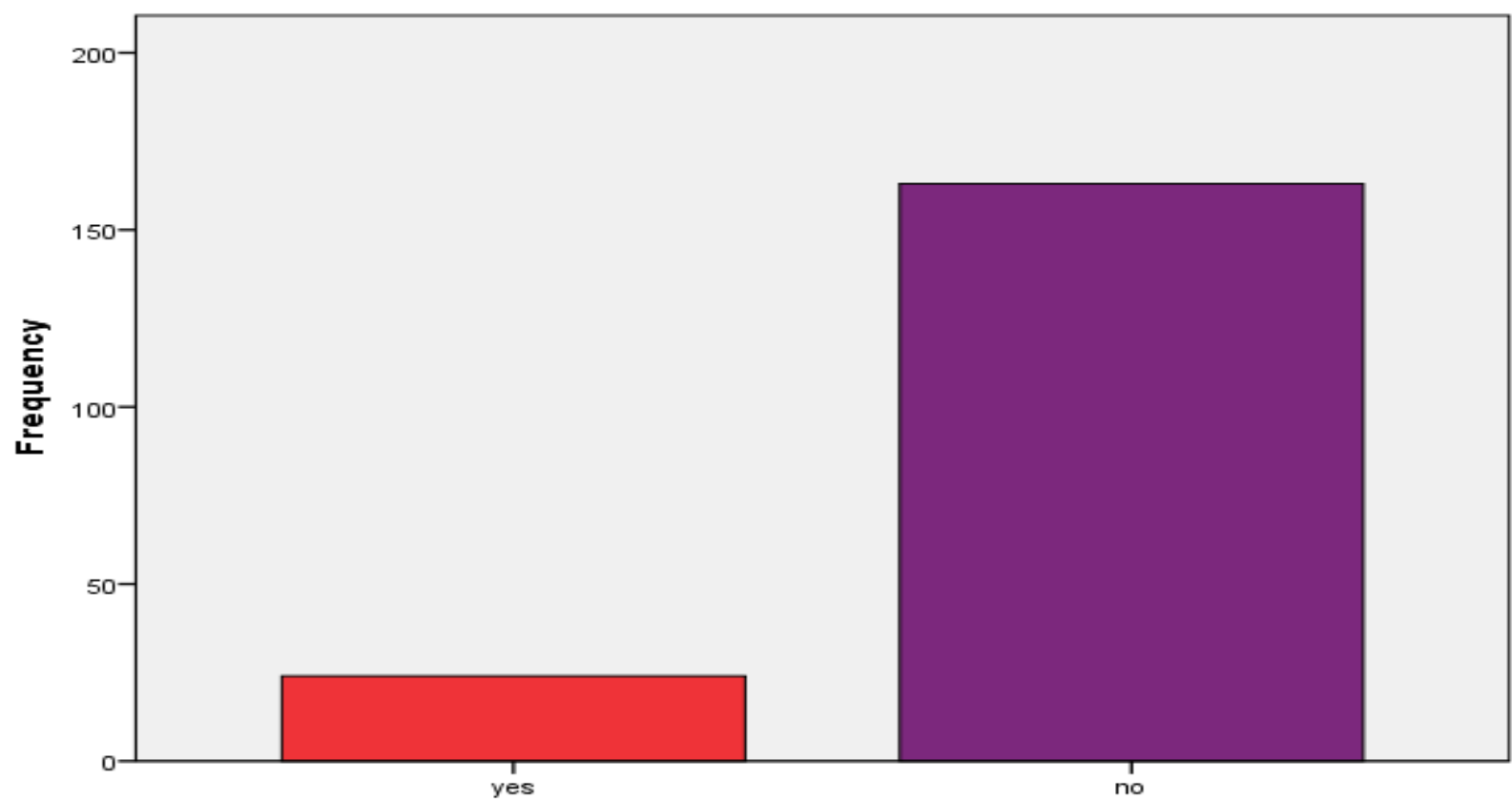

Figure 1: Respondents that have experienced GBV during pregnancy

From the table above, twenty-three $(12.3 \%)$ have experienced gender based violence while one hundred and sixty-four (87.7\%) have not experienced GBV.

Table 2: Respondents that were physically violated

\begin{tabular}{l|lc} 
Variable & Frequency & Percent (\%) \\
\hline Physically violated during pregnancy & 23 & 12.3 \\
Yes & 164 & 87.7 \\
No &
\end{tabular}

Out of the 187 respondents, one hundred and sixty-four (87.7\%) have not been physically violated during pregnancy while twenty-three $(12.3 \%)$ have been physically violated during pregnancy.

\section{Table 3: Method of physical violation used on respondents}

\begin{tabular}{l|ll} 
Variable & Frequency $(\boldsymbol{n}=23)$ & Percent (\%) \\
\hline Beating & 15 & 65.2 \\
Pulling hair & 1 & 4.3 \\
Slap & 3 & 13.0 \\
Burning & 4 & 17.4 \\
Usage of hot water or acid & 0 & 0
\end{tabular}

From Table 3 above, out of the twenty-four respondents that have been physically violated, fifteen $(65.2 \%)$ were physically violated by beating, four $(17.4 \%)$ were violated by burning and three $(13 \%)$ by slap.

Table 4: Physical effect from physical violation

\begin{tabular}{l|ll} 
Variable & Frequency $(\boldsymbol{n}=\mathbf{2 3})$ & Percent (\%) \\
\hline Broken bones & 1 & 4.3 \\
Wounds & 0 & 0 \\
Swelling & 3 & 13.1 \\
Pain & 19 & 81.3
\end{tabular}

The most common consequence of being physically violated during pregnancy is reported to be pain as suffered in nineteen $(81.3 \%)$ of respondents followed by swelling in three (13.1\%) respondents. 
Figure 2: Respondent that has been psychologically violated during pregnancy

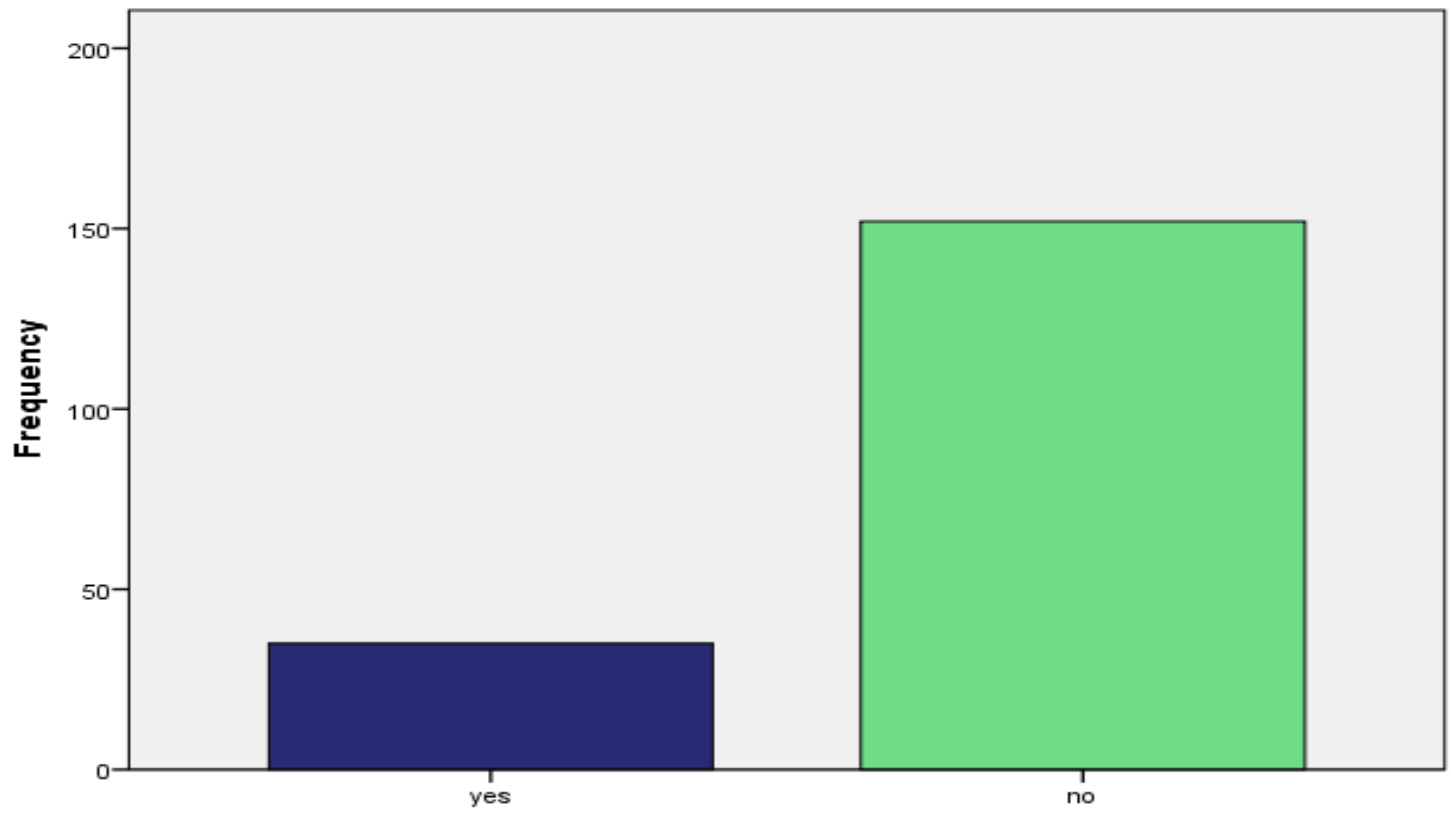

Figure 2 above shows that one hundred and fifty-two (81.3\%) respondents have not been psychologically violated while thirty-five $(18.7 \%)$ respondents have suffered psychological violation.

Table 5: Method of psychological violation during pregnancy

Variable

How respondents were psychologically violated

Verbal degradation

Threat to beat or kill

Misbehavior causing mental hurt

Polygamy

Accusation of illicit relationship

Threat to expel from home

Restriction of free movement

$\begin{array}{ll}\text { Frequency }(\boldsymbol{n}=35) & \text { Percent }(\%) \\ 24 & 68.6 \\ 0 & 0 \\ 5 & 14.3 \\ 1 & 2.9 \\ 2 & 5.7 \\ 0 & 0 \\ 3 & 8.6\end{array}$

Out of the 35 respondents that were psychologically violated, twenty-four $(68.6 \%)$ suffered verbal degradation, five $(14.3 \%)$ suffered mental hurt from misbehavior and three $(8.6 \%)$ suffered movement restriction. None of the respondents have suffered threat to beat/kill and threat to expel from home.

Figure 3: Psychological effect suffered from psychological violation during pregnancy

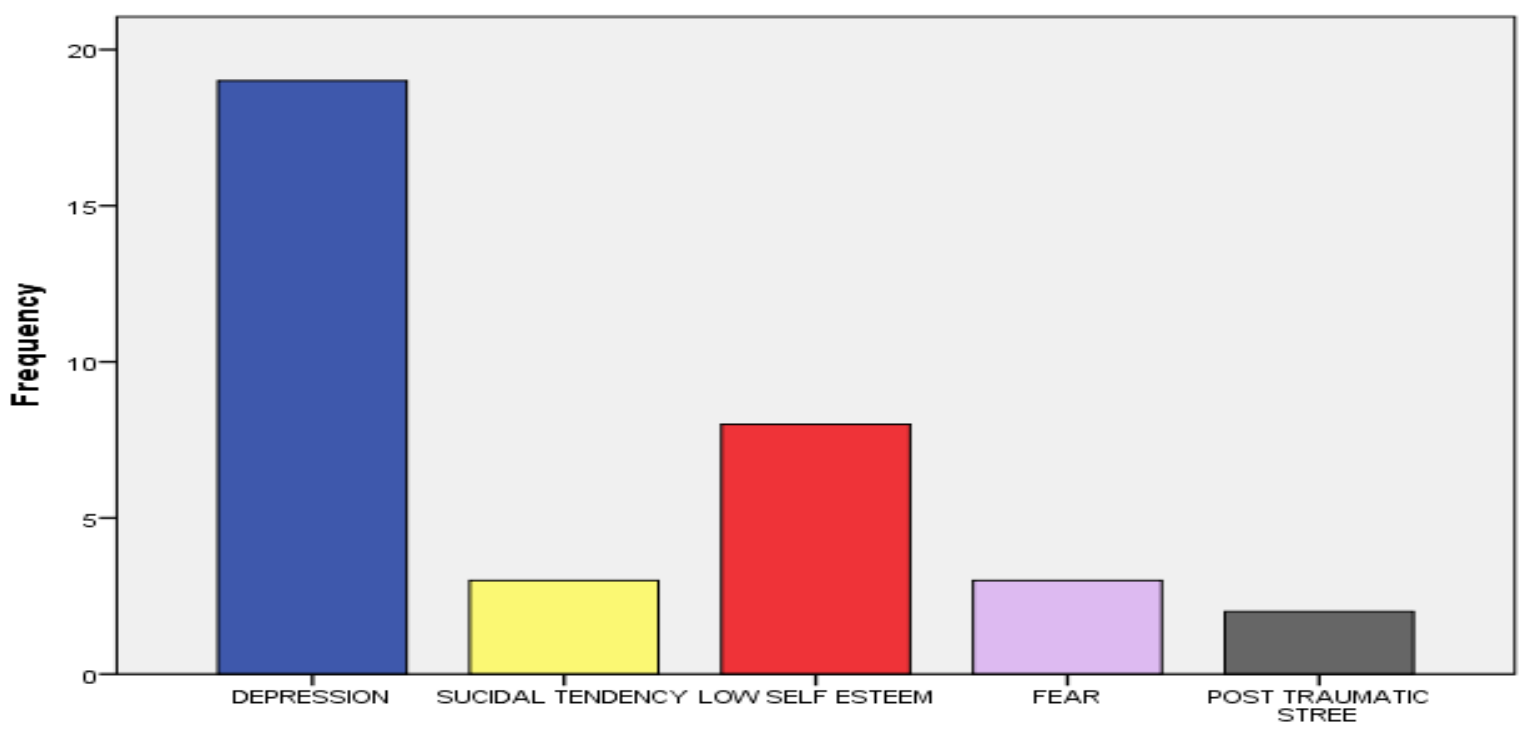

From figure 3 above it can be deduced that depression was the commonest effect of psychological violation 
suffered as nineteen out of 35 suffered it $(54.5 \%)$ while eight $(22.9 \%)$ had low self-esteem, three $(8.6 \%)$ suicidal tendency and two $(5.7 \%)$ had post-traumatic stress.

Table 6: Respondents that have been sexually violated during pregnancy

\begin{tabular}{l|ll} 
Variable & Frequency $(\boldsymbol{n}=\mathbf{1 8 7})$ & Percent $(\%)$ \\
\hline $\begin{array}{l}\text { Respondents that have been sexually violated } \\
\text { Yes }\end{array}$ & 20 & 10.6 \\
No & 167 & 89.3
\end{tabular}

Twenty (10.6\%) reported having been sexually violated during pregnancy while one hundred and sixtyseven $(89.3 \%)$ have never been sexually violated during pregnancy.

\section{Table 7: Method used in sexual violation}

How respondent was sexually violated

Forced sex without consent

Forced abortion

Contraceptives restriction

Unusual/unnatural sex

$\begin{array}{ll}\text { Frequency }(\boldsymbol{n}=20) & \text { Percent }(\%) \\ 7 & 35 \\ 1 & 5 \\ 1 & 5 \\ 11 & 55\end{array}$

From table 7 above, eleven (55\%) reported that unusual/unnatural sex was the method of sexual violation suffered while seven (35\%) reported that they have forced sex without consent during pregnancy.

Table 8: Respondents that have been economically violated

\begin{tabular}{l|lc} 
Variable & Frequency $(\boldsymbol{n}=\mathbf{1 8 7})$ & Percent (\%) \\
\hline $\begin{array}{l}\text { Respondents that have been economically violated } \\
\text { Yes }\end{array}$ & 53 & 28.3 \\
No & 134 & 71.7
\end{tabular}

The table above shows that fifty-three respondents $(28.3 \%)$ have been economically violated while one hundred and thirty-four respondents $(71.7 \%)$ have not been economically violated.

Table 9: Method used in Economic Violation

Variable

How respondent was economically violated

Restriction in outdoor work

Not getting enough money to run family

Deprivation from family means to use Frequency $(n=53)$

Percent (\%)

Out of the 53 respondents that were economically violated, thirty-five $(67.3 \%)$ respondents were economically violated by not getting enough money to run family while sixteen $(30.8 \%)$ were restricted from outdoor work. See table 9 above.

Table 10 below shows that thirty-seven (51.4\%) chose to keep the incident secret after moment of violence while six (8.3\%) retaliate during moment of violence and nineteen $(26.4 \%)$ ask relatives for help and ten (13.9\%) request for help from friends.

Table 10: Measures taken during/after moments of violence

Variables

Respondents response during/after violence

Kept incident secret

Retaliate

Ask relatives for help

Ask friends for help

Report to police

Seek help from political leaders

\begin{tabular}{|ll|} 
Frequency & Percent $(\% \boldsymbol{n}=74)$ \\
\hline 37 & 50 \\
6 & 8.2 \\
19 & 25.6 \\
12 & 16.2 \\
0 & 0 \\
0 & 0 \\
\hline
\end{tabular}

Table 11: Perpetrator in cases of violence

\begin{tabular}{l|lll} 
Variables & Frequency & Percent $(\% \mathbf{n = 1 8 9 )}$ & Cumulative percent $(\boldsymbol{n}=74)$ \\
\hline $\begin{array}{l}\text { Perpetrators } \\
\text { Husband }\end{array}$ & 55 & 29.4 & 74.3 \\
Mother-in-law & 5 & 2.7 & 6.8 \\
Father-in-law & 2 & 1.1 & 2.7 \\
Community people & 5 & 2.7 & 6.8 \\
Others & 7 & 3.7 & 9.5
\end{tabular}

In table 11 above, fifty-five women identified their husbands as the perpetrator of violence while seven respondents chose others (which included; brothers, uncles, etc) and five respondents identified mother-in-laws as perpetrators of violence during pregnancy. 


\section{Figure 4: Frequency of violation}

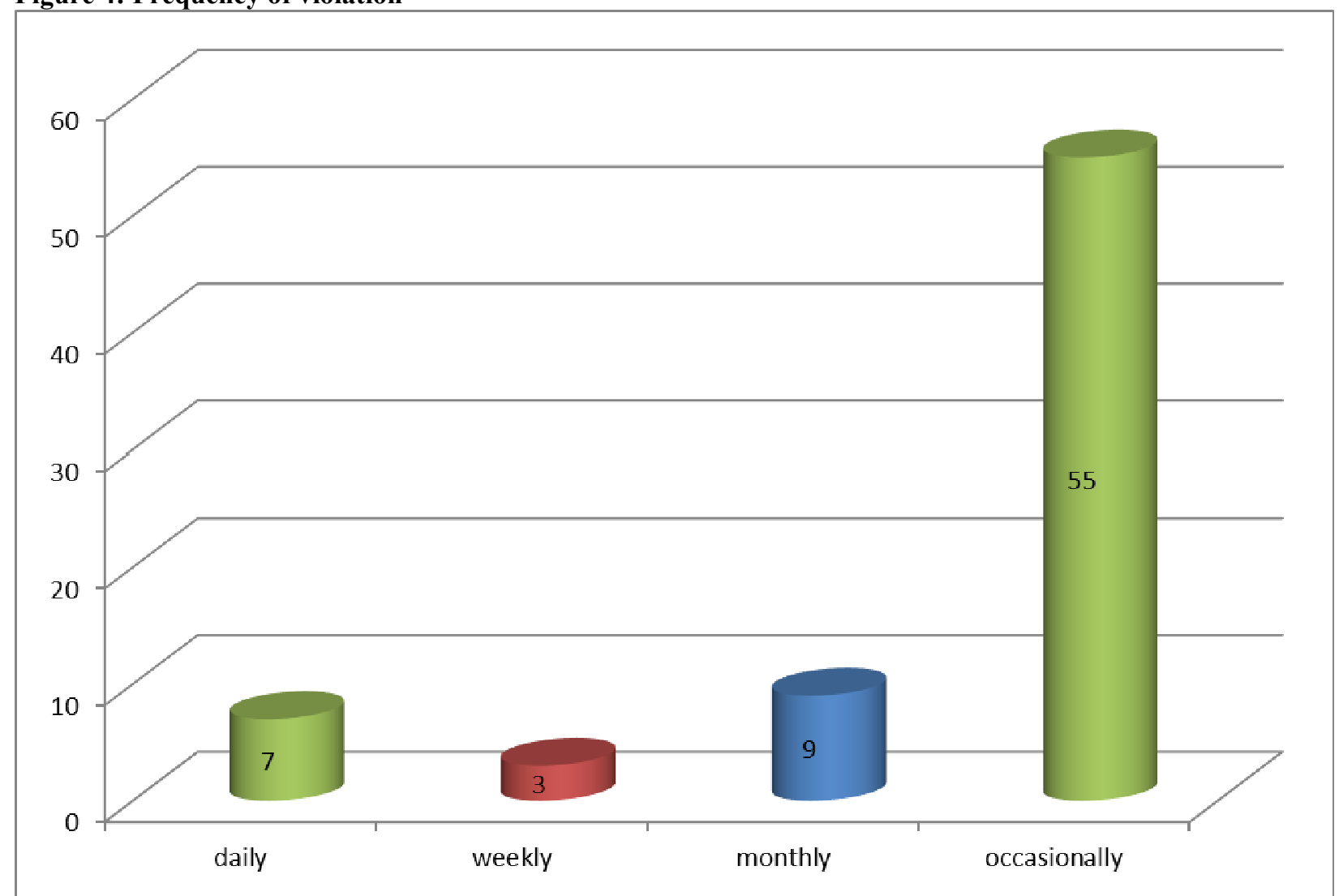

The figure above shows that, 55 respondents were violated occasionally, while 9 reported being violated monthly and 7 reported a daily violation.

\section{Figure 5: Causes of violence}

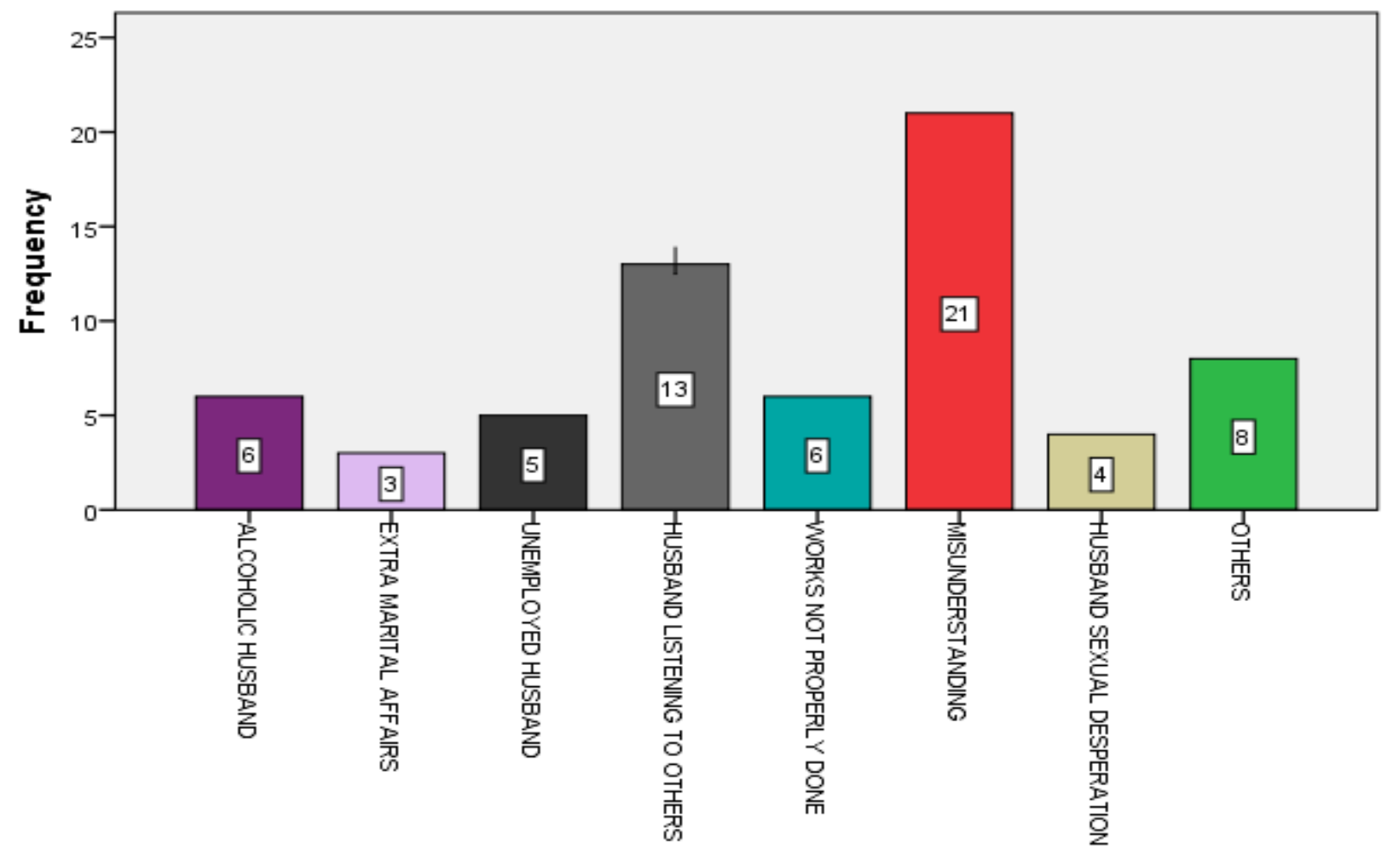

The figure above shows that 21 women reported misunderstanding to be the cause of the violence they suffer, 13 respondents pointed to the fact that husband listen to other people, 8 respondents pointed to others 
(which include; delay in marriage) and 6 reported that the violence they suffer is because their husbands are alcoholic.

Table 12: Respondents that have received treatment after violence

\begin{tabular}{l|ll} 
Variable & Frequency $(\boldsymbol{n}=74)$ & Percent $(\%)$ \\
\hline $\begin{array}{l}\text { Have you been treated after violence } \\
\text { Yes }\end{array}$ & 4 & 5.4 \\
No & 70 & 94.6
\end{tabular}

Out of the 74 respondents that have been violated physically, psychologically or sexually, four (5.4\%) have received treatment after violence while seventy (94.6\%) have never received treatment after violence.

Table 13: Solutions to stopping violence

Variable

Solutions to stop violence

Women empowerment

Report to police

Community awareness

Help from media

NGO/INGO involvement

Others

Out of the 74 respondents that have been violated, fifty-two (70.3\%) thinks women empowerment will stop the violence against them, eight (10.8\%) thinks community awareness will stop violence and a meager four (5.4\%) thinks NGO/INGO will be of help in reduction of violence against them.

Table 14: Relationship between educational status and physical violation of females attending COOUTH ANC

\begin{tabular}{|c|c|c|c|c|}
\hline & \multicolumn{2}{|c|}{ Physical Violation } & \multirow[b]{2}{*}{$\mathbf{X}^{2}$} & \multirow[b]{2}{*}{ P-value } \\
\hline & Yes & No & & \\
\hline \multicolumn{3}{|c|}{ Educational status } & \multirow{6}{*}{$27.359 *$} & \multirow{6}{*}{0.204} \\
\hline Primary & $\begin{array}{l}0 \\
0.0 \%\end{array}$ & $\begin{array}{l}1 \\
100 \%\end{array}$ & & \\
\hline Secondary & $\begin{array}{l}12 \\
32.4 \%\end{array}$ & $\begin{array}{l}25 \\
67.6 \%\end{array}$ & & \\
\hline Tertiary & $\begin{array}{l}9 \\
6.2 \%\end{array}$ & $\begin{array}{l}137 \\
93.8 \%\end{array}$ & & \\
\hline No Formal & $\begin{array}{l}2 \\
66.7 \%\end{array}$ & $\begin{array}{l}1 \\
33.3 \%\end{array}$ & & \\
\hline TOTAL & 23 & 164 & & \\
\hline
\end{tabular}

The P-value of the above is 0.204 which is above the reference point of 0.05 , hence, it is statistically not significant. This shows that there is no relationship between the respondents' highest level of education and their being physically violated.

Table 15: Relationship between educational status and psychological violation of women attending COOUTH ANC

\begin{tabular}{|c|c|c|c|c|}
\hline & \multicolumn{2}{|c|}{ Psychological violation } & \multirow{2}{*}{$\mathbf{X}^{2}$} & \multirow{2}{*}{ P-value } \\
\hline & Yes & No & & \\
\hline \multicolumn{3}{|c|}{ Educational status } & \multirow{6}{*}{$0.936^{*}$} & \multirow{6}{*}{0.006} \\
\hline Primary & $\begin{array}{l}0 \\
0.0 \%\end{array}$ & $\begin{array}{l}1 \\
100 \%\end{array}$ & & \\
\hline Secondary & $\begin{array}{l}8 \\
21.6\end{array}$ & $\begin{array}{l}29 \\
78.4 \%\end{array}$ & & \\
\hline Tertiary & $\begin{array}{l}26 \\
17.8 \%\end{array}$ & $\begin{array}{l}120 \\
82.2 \%\end{array}$ & & \\
\hline No formal & $\begin{array}{l}1 \\
33.3 \%\end{array}$ & $266.7 \%$ & & \\
\hline TOTAL & 35 & 152 & & \\
\hline
\end{tabular}

The P-value of the above is 0.006 which is below the reference point of 0.05 , hence, It is Statistically significant. This shows that there is a relationship between the educational status and their being psychologically violated. 
Table 16: Relationship between Respondents Highest Level of Education and Economic Violation

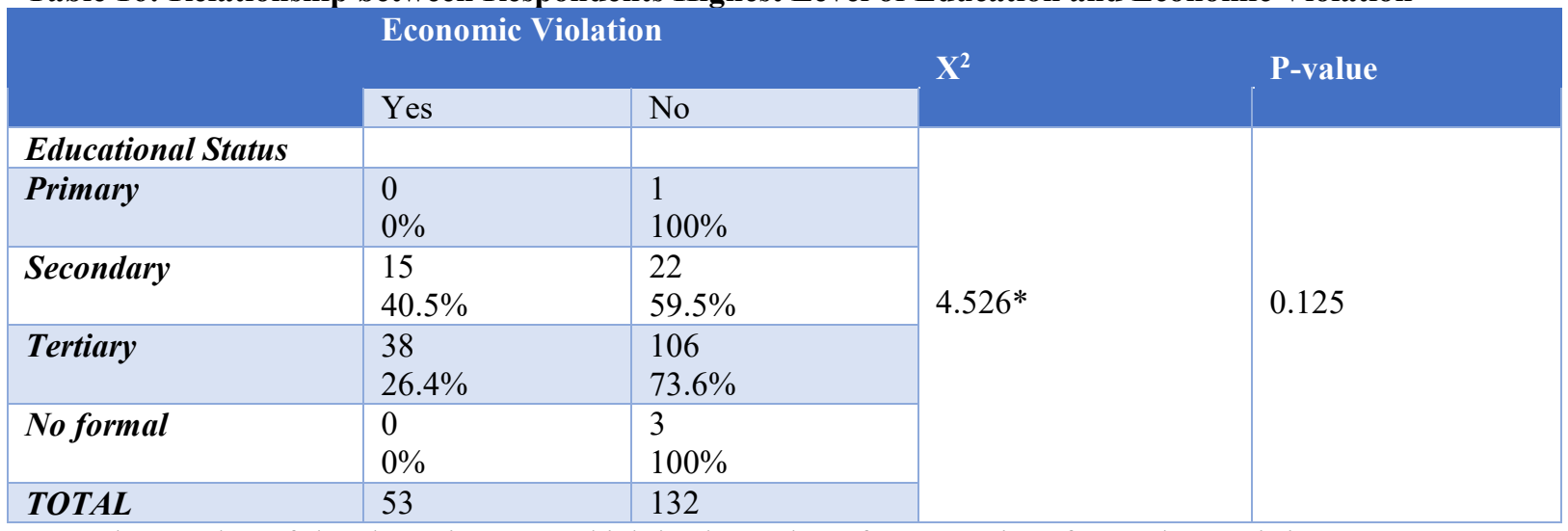

The P-value of the above is 0.125 which is above the reference point of 0.05 , hence, it is Statistically not significant. This shows that there is no relationship between the highest level of education and their being economically violated.

Table 17: Comparing respondents' marriage duration and their being physically violated

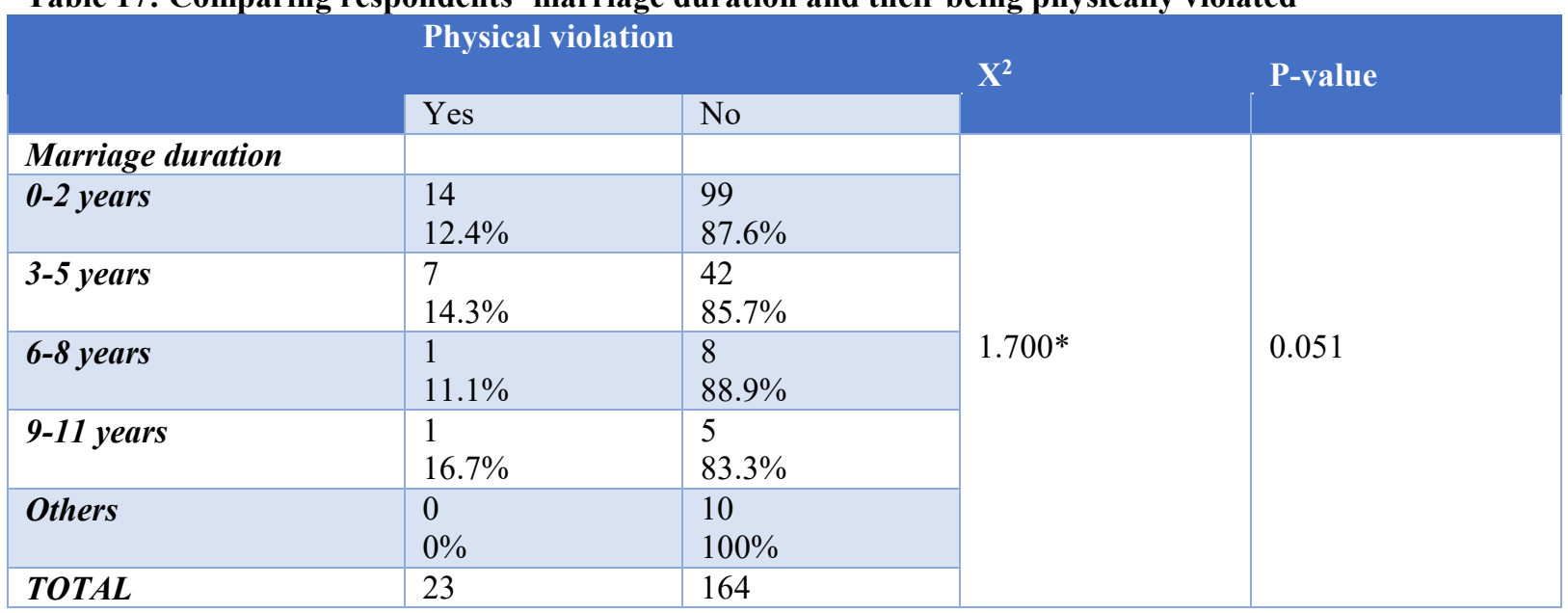

The P-value of the above is 0.051 which is equivalent to the reference point of 0.05 when put in two decimal places, hence, it is Statistically significant. This then shows that there is a relationship between respondents' marriage duration and their being physically violated.

Table 18: Comparing respondents' marriage duration to their being sexually violated

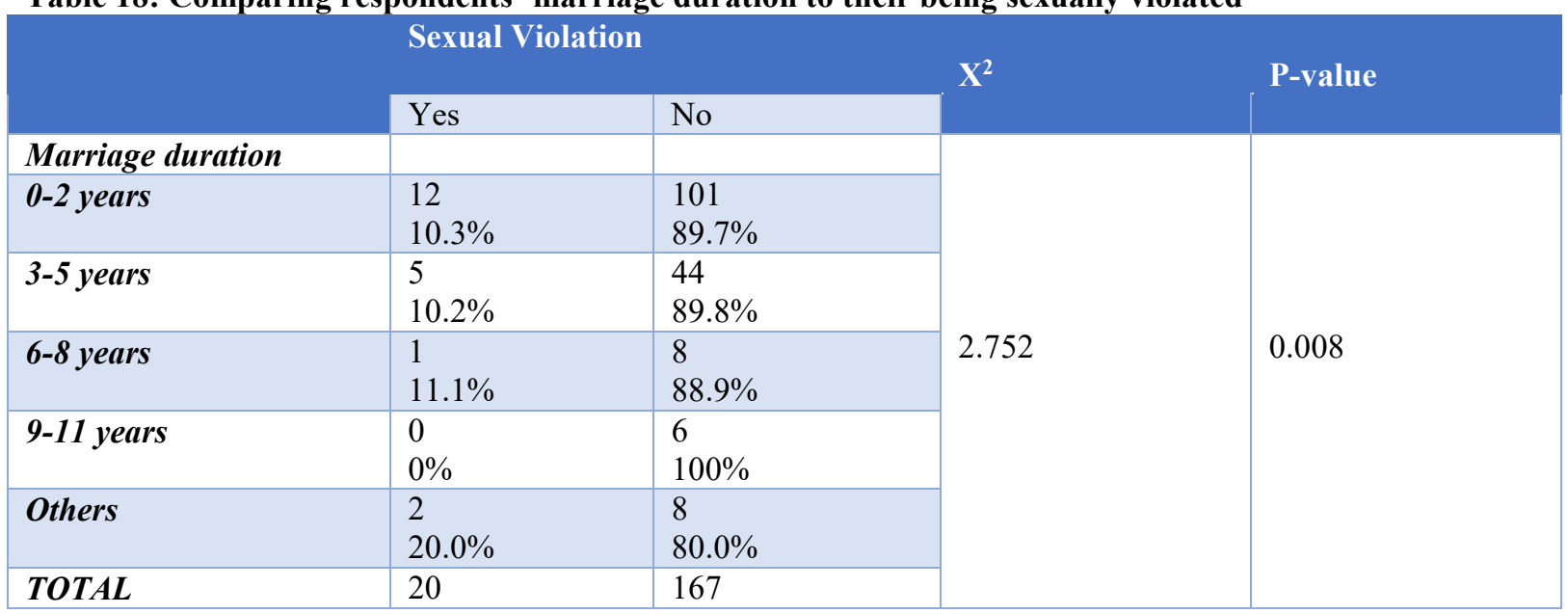

The P-value of the above is 0.008 which is less the reference point of 0.05 , hence, it is Statistically significant.

This then shows that there is a relationship between respondents' marriage duration and physical violation of women attending Ante-natal clinic in COOUTH, Amaku Awka. 


\section{Discussion}

This research assessed the prevalence of domestic violence among pregnant women undergoing antenatal care in Chukwuemeka Odumegwu Ojukwu University, Amaku Awka. The research attempted to clearly answer the research questions.

\section{Prevalence of Gender Based Violence Amongst Pregnant Women}

From the research conducted, out of 187 respondents, only $12.3 \%$ have experienced any form on gender based violence while pregnant. This prevalence tallies closely with the rate of GBV in the Canada (6-15\%). This is so regardless of the supposed high rate of GBV in developing countries especially in Africa where women right is yet to have a break because the research population was restricted to pregnant women. Owing to the way procreation is highly regarded in south eastern Nigeria, the prevalence is low as when compared to other population. When compared to the United Kingdom with a prevalence of 3.4\%, the margin is quite wide. This is owing to the fact that development cut across through their women's health and high litigations against such actions in UK.

Coming to Nigeria, a prevalence rate of $15.5 \%$ among pregnant women was given and this is within range of the result gotten. It is a bit lower owing to the fact that south eastern Nigerians are more gender conscious than their northern contemporaries which were factored in the aforementioned prevalence. Also the women are more educated than northerners as the result shows also that high academic attainment tend to reduce the rate of GBV.

\section{Type of Violence Against Pregnant Women}

The most common type of violence seen amongst the pregnant women was physical abuse which grossed $65.2 \%$. This physical violence involves mostly beating, then burning and slapping. Physical violence was followed by economic abuse (28.3\%). Then psychological and sexual abused followed suit with 18.7\% and $28.3 \%$ respectively. In comparison with result from Ethiopia, the above wasn't observed as the commonest type of abuse was psychological (24.9\%) followed by Sexual (14.8\%) and Physical violence (11.3\%). When compared with the result gotten from a research done in Jos, Nigeria, there is a shift in order as sexual violence was the most common as it consists $60.9 \%$ of all domestic violence. This was followed by psychological abuse (20.3\%) and then physical abuse $(18.7 \%)$. This is largely due to the difference in the religious and socio-cultural orientation of the two regions which affects the attitude to their partners.

\section{Cause of Gender Based Violence Amongst Pregnant Women}

The most common cause of violence amongst the study population is misunderstanding on diverse issues arising in the family as against the report in Jos which shows that most abuse was because of alcoholic husbands, followed by infidelity. In this study, alcoholic husband only came third as the commonest cause as pressure on the husband from friends and family and the husband heeding to them resulted in violence more than the effect of alcohol. In faraway India, the commonest cause is mostly due to sex choice of unborn baby as violence increases when the woman is pregnant with a female child as there is a high demand of male child. Such trend has not been established here partly due to the low practice of in-utero sex determination of fetus.

\section{Relationship of The Perpetrators to Women}

The study is consistent with the results from Jos, Nigeria and far away China in identifying the commonest perpetrators of GBV against women to be their Husbands as it grossed $73.4 \%$ in this study. This is followed by the mother-in-law of the woman in all the studies. The remainder were then shared between co-wives, brothersin-law, step children etc.

\section{Response and Reactions of Women}

The most common response in this research (50\%) also corresponds with the most common reaction as seen in a study done in Zaria (35.9\%) and this is keeping the violence a secret. This is large due to the fact that the women feel ashamed of discussing such episodes or seeking for help or just the fear of the unknown. Also socio-cultural orientation plays a huge role here as the society is comfortable with male dominance, being laden with gender inequality, so the women most times just take every violence, hoping and praying for the best as divorce is frowned upon in the society. Also, the husband in most cases is the breadwinners of the family, so the woman rather keeps it secret and try to please the husband more.

This research shows that $41.8 \%$ will ask for help, $25.6 \%$ from family relatives while $16.2 \%$ from friends. This trend also tallies with the study done in Zaria. Retaliation of victims of GBV was seen in $8.2 \%$ and this can also be linked to both religious and socio-cultural reasons. Then of all respondents that were exposed to violence, only 5.4 women went to the doctor for treatment. 


\section{Conclusion}

In conclusion, Gender based violence remains a major health concern in the society, more so in pregnant women. In the study above, $12.3 \%$ were victims of violence and this is a mirror to show how much more is seen in both pregnant and non-pregnant women. Also in the Northern Nigeria where women's health is at a much lower concern due to ignorance, poverty and socio-cultural practices, the prevalence will be higher. Putting all these together, it is apt to say that massive enlightenment campaign to boost community awareness of the dangers of GBV, women empowerment and social reorientation are necessary to curtail the incidence of GBV in our society.

\section{Recommendations}

The Nigerian Government has historically made inadequate responses to humanitarian matters such as domestic violence which was usually seen as a private matter. Violence against Persons (Prohibition) (VAPP) Act was passed earlier in 2015 marking a progression in government attention towards domestic violence issues. To prevent government from appearing inconsistent, we strongly recommend that relevant organizations such as the National Human Rights Commission (NHRC) should ensure that repercussions were in place for recalcitrant officers of the law who fail to provide consistent timely response to abuse reports.

Furthermore, the taboo surrounding domestic violence discussion and accurate data reporting should be discouraged. Women should be encouraged to speak up when such event happens and the violence should be followed up adequately by the necessary authority without bias. We therefore, also recommend that it will be necessary to remove the stigma surrounding domestic violence through creation of government sponsored community programs that directly addresses physical and psychological violence. Non-Governmental Organizations should also facilitate partnerships between the government and relevant agencies such as the United Nations, World Bank, Gates foundation, etc. Such partnerships would facilitate project funding and increase government accountability.

\section{REFERENCES}

1. Samjhana G, Jeevan A. Gender-based Violence Among Pregnant Women; Korea Centers for Disease Control and Prevention>Osong Public Health and Research Perspectives, [internet], [cited June 5 2018]. Available from https://www.ncbi.nlm.nih.gov/pmc/articles/PMC4850410/

2. National Gender Based Violence And Health Program. Gender Based Violence: What is Gender Based Violence? [Internet], [Cited June 4 2018] Available fromhttp://www.gbv.scot.nhs.uk/gbv

3. Maternal and Early Years for early years workers. Abuse, Neglect and Gender-based Violence in Pregnancy: What is Gender Based Violence? [Internet] [cited October 52018] Available from www.maternalyears-andearly-years.org

4. Isaac Ogweno O, Margaret Keraka N, HarrysonEtemesi A: Intimate Partner Violence in Pregnancy among Antenatal Attendees at Health Faciities in West Pokot County, Kenya CPanAfrican Medical Journal ISSN:1937-8688 Vol. 31 [cited June 52018] Available from www.panafrican-med-journal.com

5. Arulogun O, Jidda K: Experiences of Violence among Pregnant Women Attending Ante-Natal Clinics in Selected Hospitals in Abuja, Nigeria. CSierra Leone Journal of Biomedical Research ISSN 2076-6270 (Print) Vol. 3(1) pp. 43-48, April, 2011 [Cited June 4 2018] Available from: https://www.ajol.info/index.php/sljbr/article/download

6. Heise L. Violence against women; global organizing for change .In: Edleson JL, Eisikovits ZC, editors. Future interventions with battered women and their families. Thousand Oaks, California: Sage publications, 1996. p.7-33.

7. Bacchus M, Loraine C, Gill M, Susan B, Alison Haworth. "Prevalence of domestic violence when midwives routinely enquire in pregnancy" .BJOG: An international journal of obstetrics and gynecology 111.5, 2004.

8. CDC, "Safe Motherhood", U.S. Department of health and human services, 2002.

9. Huth-Bocks AC, Levendosky AA, Bogat GA. "The effects of domestic violence during pregnancy on maternal and infant health, April 2002.

10. Torres S; Campbell J; Campbell DW; et al. Abuse during and before pregnancy, prevalence and cultural correlates, 2000.

11. O' Donnell S, Fitz-Patrick M, Mckenna P. Abuse in pregnancy- the experience of women. November 2000.

12. WHO: World Health Organization, Violence by intimate partners.

13. Parker B, MC Farlane J, Soekenk, Torres S, Campbell D. Physical and emotional abuse in pregnancy: a comparison of adult and teenage women. 1993.

14. N.C .Department of Health and Human Services. "Physical violence: Pregnancy Risk Assessment Monitoring System (www.schs.state nc. us/SCHS/data/prams.cfm).

15. Meerambika N, Gupta J, Vinay G, Kundu A. Domestic Violence during pregnancy in India. 2011.

16. Leung WC, Leung TW, Lam YY, HO PC. The Prevalence of Domestic Violence Against Pregnant Women in a Chinese Community .Int J Gynecol obstet. 1999. 
17. Kadmodu P, Shrawan K, Madhu S. Prevalence Of Gender Based Violence among pregnant women: A hospital based study. Nepal Journey of Obstetrics and Gynecology 5(2), July 2011.

18. Tenaw Y, Tesfaye G, Gudina E, Habtamy M. Magnitude of Domestic Violence and Associated Factors among Pregnant Women in NuletEjjuEnessie District, Northwest Ethiopia. 10 Nov 2014, Volume 2014, Article ID 484897, 8pages. http://dx.doi.org/10.1155/2014/484897.

19. Adewale O Ashimi, Taiwo G Amole. Prevalence and predictors for domestic violence among pregnant women in a rural community Northwest Nigeria, 2015, volume 56, page 118-121.

20. Emuladu F, Esther A, Lornengen B. Domestic Violence Among Pregnant women attending antenatal clinic in a PHC facility in Jos North LGA Plateau state Nigeria. E3 journal of medical research. June 2012.

21. Ameh N, Abdul M. Prevalence of domestic violence amongst pregnant women in Zaria Nigeria. Annals of African Medicine, 2014. Vol 3, page 3-4.

22. Awusi V, Okeleke O, Anyanwu B. Prevalence of domestic violence during pregnancy in Oleh, a suburban Isoko community, Delta state, Nigeria. Benin Journal of Postgraduate Medicine, 2002.

23. "Awka" [internet] available fromhttps://en.m.wikipedia.org/wiki/Awka, accessed 29 $9^{\text {th }}$ May, 2018.

24. Vol. 94. Abuja: 2006. National Population Commission. Provisional Census Results. Federal Republic of Nigeria Official Gazette 15/5/07; p.24.

25. Araonye MO. Research methodology with statistics for health and social sciences. $1^{\text {st }}$ Ed. Ilorin; Nathadex Publisher; 2003.

26. Olagbuji B, Ezeanochie M, Ande A, Ekaette C. Trends and determinants of pregnancy-related domestic violence in a referral centre in southern Nigeria. Internatonal Journal of Gynecology and Obstetrics, 2010. p. 101-103 